\title{
Társadalmi egyeztetés a közlekedésfejlesz- tés szolgálatában - a Consul keretrendszer adaptációjának tanulságai
}

\begin{abstract}
A közösségi beruházások megvalósítási folyamatában egyre nagyobb hangsúlyt kap a társadalmi észrevételek figyelembevétele. Jelen tanulmány a BKK Zrt. SMART-MR kutatás-fejlesztési projektjének keretében kialakított keretrendszer segítségével tíz közlekedésfejlesztési projekt társadalmi egyeztetésének folyamatát és eredményeit mutatja be, amelyek jelentős mértékben hozzájárulhatnak a jövőbeli társadalmi értékelési folyamatok eredményességéhez.
\end{abstract}

DOI 10.24228/KTSZ.2019.6.1

Vörös Tünde ${ }^{1}$ - Juhász Mattias ${ }^{1}$ - Kerényi László Sándor ${ }^{2}$ - Fejes Balázs ${ }^{2}$

E-mail: tvoros@ts-c.hu,mjuhasz@ts-c.hu, laszlo.kerenyi@bkk.hu, balazs.fejes@bkk.hu

'Trans-Sport Consulting, ${ }^{2}$ Budapesti Közlekedési Központ

\section{BEVEZETÉS}

Számos gazdasági ágazatban megfigyelhető, hogy a közösségi forrásokból megvalósuló beruházások esetén előtérbe kerülnek a társadalmi észrevételek [1], [2]. A társadalmi egyeztetés folyamatának a tervezési fázisba történő beépülése nem csupán az adott beruházás müszaki tartalmát, gazdasági jellemzőit befolyásolhatja a felhasználó közösség számára kedvezö irányban, hanem nagymértékben hozzájárulhat egy társadalmi szempontból hasznos projekt elfogadottságának növeléséhez, vagy akár a társadalmi preferenciák alapján nem kívánatos beruházás elkerüléséhez is [3].

A fenntartható városi mobilitás tervezési (Sustainable Urban Mobility Planning, SUMP) gyakorlatának előtérbe kerülésével a közlekedési ágazatban is megfigyelhető a társadalmi észrevételek fontosságának növekedése és beépülése a stratégiai tervezési és projekt előkészítési folyamatokba $[4,5,6]$. Az egykori Nemzeti Fejlesztési Minisztérium által 2017-ben kiadott hazai SUMP útmutató például a következőképpen fogalmaz: „A mobilitási terv kidolgozása során kiemelten fontos szempont a széles körü, érdemi partnerség megvalósitása, a tervezés és a megvalósitás fázisaiban egyaránt. Az érintettek bevonásával a tervezés során a városi mobilitást érintő döntések, így maga a mobilitási terv is jelentős legitimációt nyer, elfogadottsága, támogatottsága erősödik." [7] Ezzel párhuzamosan alulról építkező, bottom-up jellegű kezdeményezéseket is azonosíthatunk a hazai gyakorlatban, mint például a Budapest Dialog vagy a jarokelo.hu, illetve egyaránt találkozhatunk a civil, a piaci és a kormányzati szektor szereplői által támogatott kezdeményezésekkel is, mint a MIZUglónk, az Óbuda-Békásme- 


\section{Közlekedésfejlesztés}

gyer Városfejlesztő weboldalak, valamint a Budafoki út közösségi tervezésének példája. Érdemes megemlíteni, hogy a hazai közlekedésfejlesztési elképzelések társadalmi egyeztetésének mind program, mind projekt szinten több évtizedes gyakorlata van (pl. az 1990-es években a Lágymányosi híd megépítését övező társadalmi egyeztetés, a 2013-as Nemzeti Közlekedési Stratégia társadalmi egyeztetése vagy az egyes közlekedésfejlesztési operatív programok társadalmasítása); ugyanakkor a korábban tapasztalt eljárások tartalmukat, mélységüket és jellegüket tekintve sem azonosak a SUMP módszertan vonatkozásában előtérbe került, illetve az alulról szerveződő társadalmasítási, közösségi tervezési metódusokkal.

Jelen tanulmány a BKK Zrt. SMART-MR kutatás-fejlesztési projektjének keretében kialakított keretrendszer segítségével tíz különböző közlekedésfejlesztési projekt társadalmi egyeztetésének folyamatát és eredményeit mutatja be. Egy, a társadalmi egyeztetést és értékelést segítő eszközök, platformok nemzetközi gyakorlatának vizsgálatára kiterjedő benchmark kutatás eredményeként a nyílt forráskódú Consul platform [8] került kiválasztásra, az elsősorban Budapestet és vonzáskörzetét érintő közlekedési projektek társadalmi egyeztetésének céljával. A korábban tapasztalt társadalmi egyeztetési gyakorlattól eltérően e platform alkalmazásával a SUMP megközelítésnek megfelelő, formalizált társadalmasítás folytatható le, amelyből összehasonlítható, illetve kvantitatív jellegű következtetések vonhatók le. A platform tesztelését, annak eredményeit és az abból levonható tanulságokat a BKK megbízásából készült szakértői anyag [9] alapján mutatják be a következő fejezetek.

\section{A CONSUL KERETRENDSZER ADAPTÁCIÓJA KÖZLEKEDÉSFEJ- LESZTÉSI PROJEKTEK TÁRSA- DALMI ÉRTÉKELÉSÉNEK CÉLJÁ- VAL}

A Consul keretrendszer 2019 januárjában megvalósuló tesztje során egy olyan online felület került kialakításra, amely korlátozás nél- kül minden érdeklődő számára elérhető volt, így nem csupán a budapesti lakhellyel rendelkezők számára nyílt lehetőség véleménynyilvánításra [10]. Az 1. ábra a kialakított válaszadó felületet illusztrálja.

A rendszer tesztelése során a 1247/2016. (V. 18.) Korm. határozatban [11] közzétett IKOP projektlista 2018. november 18-tól hatályos legfrissebb változatának tíz fővárosi vonatkozású projektje került feltöltésre a kialakított felületre, amelyek a következők:

1. M0 körgyürü - északi szektor (10-11. sz. föutak között),

2. Déli összekötő vasúti Duna-híd korszerüsítése,

3. Budapest Liszt Ferenc nemzetközi repülőtér kötöttpályás kapcsolatának kialakítása,

4. M3-as metróvonal infrastruktúra rekonstrukciója,

5. Trolibusz jármübeszerzés és kapcsolódó infrastruktúra-fejlesztés,

6. 1-es villamos meghosszabbítása az Etele térig,

7. $\mathrm{P}+\mathrm{R}$ parkolók építése,

8. Villamos jármübeszerzés,

9. Déli HÉV vonalak fejlesztése: H6-H7 vonalak korszerüsítése, összekötése és belvárosi meghosszabbítása (Kálvin tér - Csepel és Ráckeve között),

10. Budapest elővárosi vasúti rendszerének fejlesztése (S-Bahn rendszer kiépítése) új vasúti összekötő alagút építésével.

A Kormányzat és a Fővárosi Önkormányzat által támogatott közlekedésfejlesztési projektjavaslatokról a müszaki tartalom rövid leírása, szakértői költségbecslés, valamint a térbeli elhelyezkedés ismertetése állt rendelkezésre a válaszadók számára. Ezen információk ismerete alapján - a Consul keretrendszer kötöttségeit is figyelembe véve - a következő két módon kerültek összegyüjtésre a társadalmi észrevételek.

1. Az egyes projektjavaslatok megvalósításának támogatása (voting): a projektről megadott információk alapján bináris - támogatom vagy nem támogatom - válaszadási lehetőségek általi véleménynyilvánítás. 


\section{Közlekedésfejlesztés}

\section{1. ábra: A kialakított válaszadó felïlet a Consul keretrendszerben [9]}

\section{PROJEKTJAVASLATOK}

Kérjūk az alábbi kỏzlekedésfejlesztési projektjavaslatok közūl támogassa azokat, amelyek megvalósitásával egyetértl A projektjavaslatok leírását a projekt nevére kattintva érheti el. Ha még nem véglegesítette szavazatát, a projektjavaslatokat a „Tetszik" gombra kattintva tudja támogatni. Tobb projektjavaslatot is támogathat, ha meggondolta magát, szavazatát vissza is vonhatja.

$\begin{array}{lll}\text { P1. M0 körgyürü - északi szektor (10-11. sz. föutak } & \text { iE } & \begin{array}{l}\text { PROJEKTJAVASLATOK } \\ \text { FŌVÁROSI }\end{array} \\ \text { KERÜLETEK SZERINT }\end{array}$
között)

P1. MO kōrgyũrũ - északi szektor (10-11, sz. fôutak kōzött)

P2. Déli összekötő vasúti Duna-híd korszerũsítése

Déli ôsszekötỗ vasưti Duna-hid korszerũsitése

P3. Budapest Liszt Ferenc nemzetközi repülötér kötöttpályás kapcsolatának kialakitása

Budapest Liszt Ferenc nemzetkozi repolôtêr kơtottpályás kapcsolatának kialakitása Köbánya-Kispest és Monor állomások között, kb. 27 km hosszon ủj, kẻtvảgányú, villamosított, szintbeni keresztezések nélküli vasứti pálya megépitésével

2. Költségvetési terv összeállítása (budgeting): a válaszadó által hasznosnak, megvalósításra érdemesnek ítélt projektjavaslatokból adott, hipotetikus költségkeretet (1000 milliárd Ft) nem meghaladó projektcsomag összeállítása.

\section{A LEFOLYTATOTT TÁRSADALMI EGYEZTETÉS EREDMÉNYEI}

A teszt elsődleges célja a Consul keretrendszer adaptálása volt, amelynek során 280 regisztrált felhasználó vett részt a projektjavaslatok társadalmi értékelésében. Az egyes projektjavaslatok megvalósításának támoga- tására irányuló felmérésben (voting) összesen 230 felhasználó adott érvényes választ. A költségvetési terv összeállítása (budgeting) esetében már jóval kevesebb, csupán 157 értékelhető választ regisztrált a rendszer. A tesztidőszak - a SMART-MR projekttel összefüggő követelmények miatti - rövidségéből (3 nap) adódó alacsony elemszám teljeskörüen megalapozott következtetések megfogalmazására nem adott lehetőséget, ugyanakkor számos hasznos észrevétel volt azonosítható. Ilyenek például az adatsorokból kirajzolódó általános jellegü következtetések a válaszadók habitusára, a kérdésfeltevés módjára vonatkozóan. Nem vonhatók le ugyanakkor a válaszadók alacsony száma, illetve szociológiai jel- 
lemzőik ismeretének hiányában megbízható következtetések a konkrét projektjavaslatok vonatkozásában.

A lefolytatott társadalmi egyeztetés adatfeldolgozási folyamatában hat különböző mutatószám került meghatározásra az egyes projektek iránt megnyilvánuló társadalmi értékítélet jellemzéséhez:

1. a projektjavaslatra adott támogatások darabszáma $(\mathrm{db})$,

2. a projektjavaslatot támogatók aránya az érvényes válaszokhoz viszonyítva (\%),

3. a projektjavaslatok között felállított sorrend szerinti rangszám a támogatások alapján (rangszám),

4. a projektjavaslatra pénzügyi forrást allokáló válaszadók száma (db),

5. a projektjavaslatra pénzügyi forrást allokáló válaszadók aránya a költségvetési tervet (budgeting) érvényesen összeállító válaszadók között (\%),

6. a projektjavaslatok között felállított sorrend szerinti rangszám a projektjavaslatra pénzügyi forrást allokáló válaszadók száma alapján (rangszám).

A mutatószámok értékeit az 1 . táblázat tartalmazza. A bináris választási lehetőséget adó támogatás funkciót kitöltő 230 válaszadó közül a legtöbben a Déli HÉV vonalak fejlesztésével (P9) értettek egyet. Ez összesen $127 \mathrm{db}$ támogatást jelent, ami az érvényes válaszok 55,22\%-ának felel meg. A legkevesebb támogatást - 88 szavazatot, az érvényes válaszok 38,26\%-át - a Trolibusz jármübeszerzés és kapcsolódó infrastruktúra-fejlesztés címü projektjavaslat (P5) kapta. Átlagosan 108,5 támogatást kapott egy projektjavaslat, amely az érvényes válaszok 47,17\%-a. Az átlag feletti értékekkel rendelkező projektek mutatószámai szürke háttérrel találhatók meg a táblázatban.

Az 1000 milliárd forintos költségkeret allokálását - az összesen 1582 milliárd Ft összértékű projektjavaslat között - érvényesen elkészítő 157 válasz esetében a 18 milliárd $\mathrm{Ft}$ becsült költséggel rendelkező Villamos jármübeszerzés címü projektjavaslat (P8) került be a legtöbb költségvetési tervbe. A válaszadók 73,25\%-a, azaz 115-en tették be költségvetési tervükbe a projektet. A legkisebb gyakorisággal a 650 milliárd Ft becsült költséggel rendelkező Budapest elövárosi vasúti rendszerének fejlesztése (S-Bahn rendszer kiépitése) új vasúti összekötő alagút épitésével (P10) címü projektjavaslat szerepelt a képzeletbeli projektcsomagokban. Összesen 62-en szavaztak a projektnek forrást, vagyis az érvényesen elkészített projektcsomagok 39,49\%-ában szerepelt a projekt. Átlagosan egy projekt 56,50\%-os valószínűséggel került be a válaszadók által készített költségvetési tervekbe. Az átlag feletti értékekkel rendelkező projektek mutatószámai szürke háttérrel találhatók meg a táblázatban.

A válaszadók a rendelkezésre álló 1000 milliárd forintos költségvetési keretből - várakozásainkhoz képest jóval kevesebbet - átlagosan csupán 774 milliárd Ft-ot (77,4\%-ot) költöttek el. A számadat alapján a kitöltők pénzügyi tudatosságát feltételezhetjük, átlagosan 226 milliárd Ft nem került elköltésre. Tehát a válaszadók jelentős része nem töltötte ki a teljes költségkeretet. Vagyis megfigyelhető az a magatartás, hogy a kitöltők értékítéletüket követve nem válogattak be olyan projekteket, amelyeket nem tartottak hasznosnak, csupán azért, mert maradt még rendelkezésre álló forrás.

A projektjavaslatok társadalmi értékelésének változását mutatja a két értékelési mód - egyszerű támogatás és költségvetési terv készítése - között megfigyelhető különbség a társadalmi értékelést leíró mutatószámokban (1. táblázat). A 2. ábra a támogatások száma és a projektre pénzügyi forrást allokálók száma közötti különbséget mutatja be. Jól látható, hogy a támogatások száma alapján csökkenő sorba rendezett (kék szín) projektek között teljesen más sorrend állítható fel a költségvetési terv alapján (piros szín).

A kétféle értékelési módot összehasonlítva megállapítható, hogy csupán két olyan projekt (Villamos jármübeszerzés (P8), Déli HÉV vonalak fejlesztése (P9)) volt, amely mindkét értékelési mód esetén átlag feletti eredményt ért el. Emellett pedig csak egyetlen olyan pro- 


\section{Közlekedésfejlesztés}

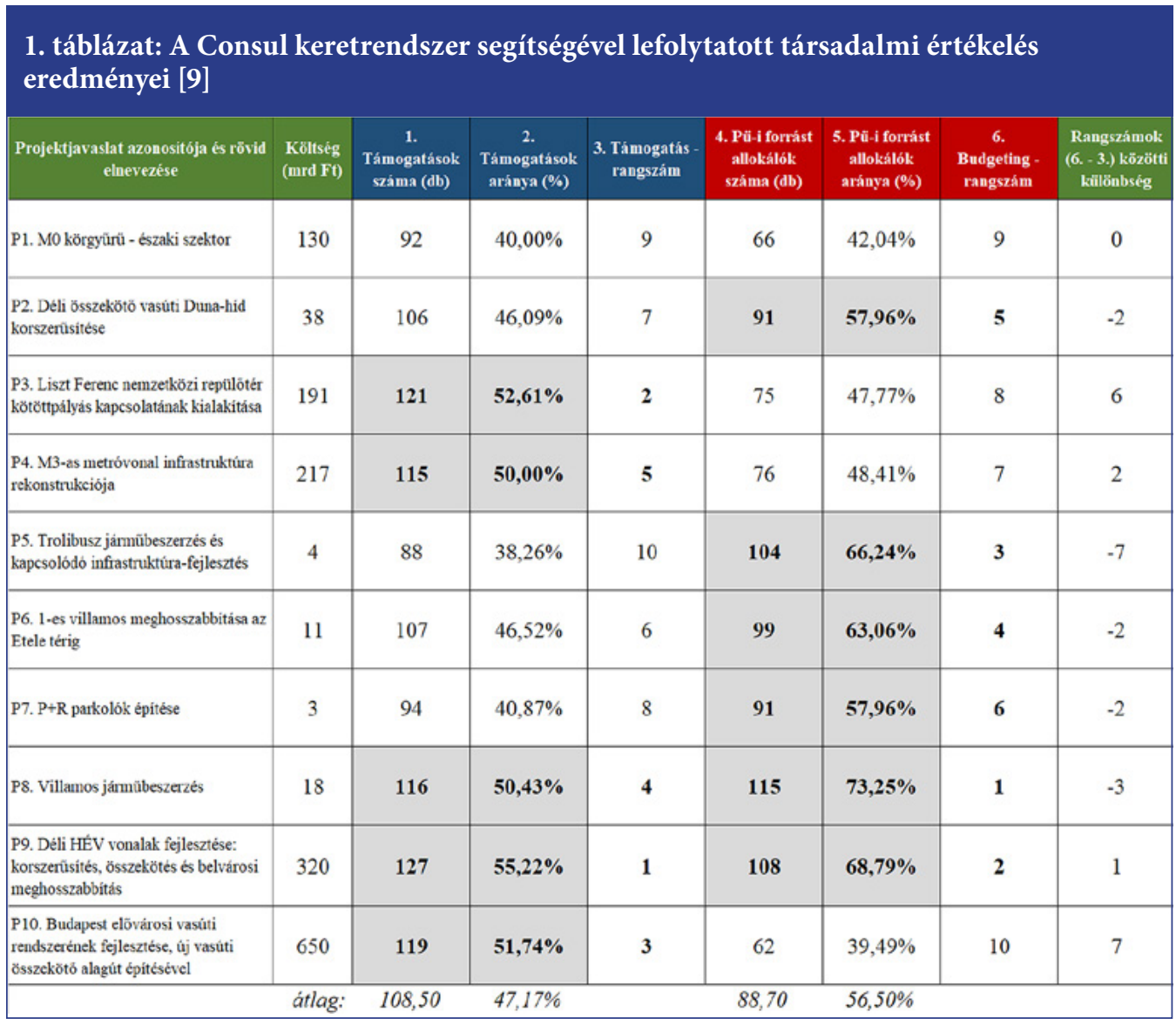

\section{2. ábra: A társadalmi értékelésben tapasztalható eltérés az egyszerü támogatás és a költségvetési terv készítése között [9]}

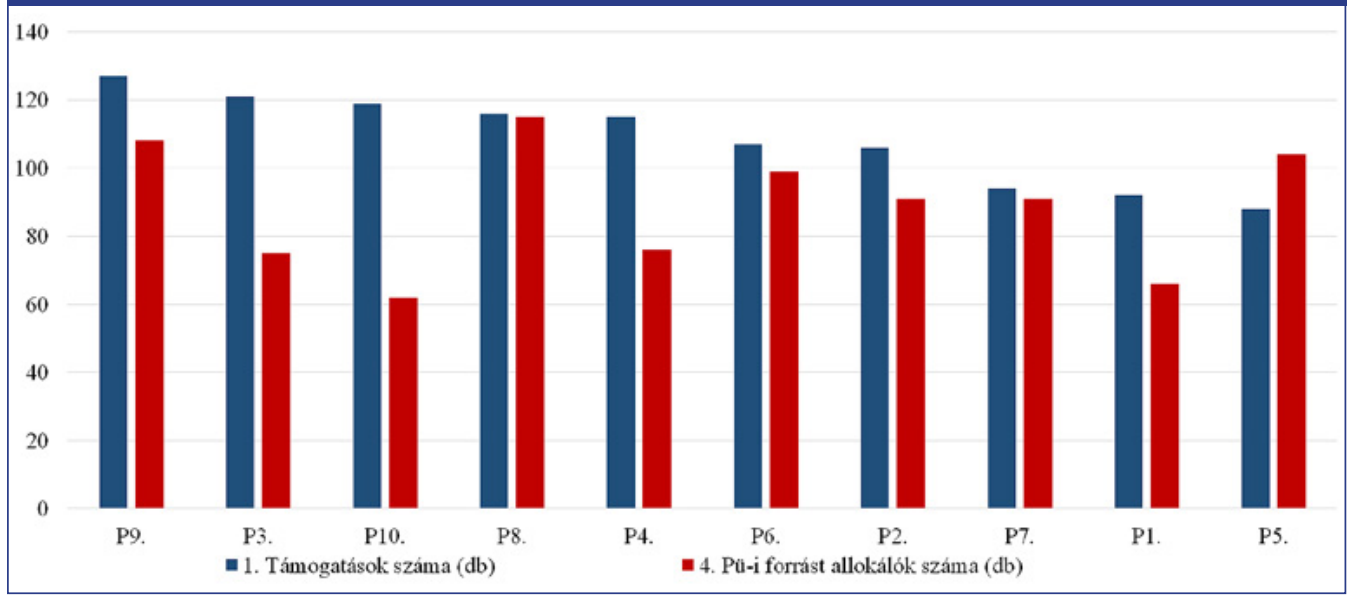


jekt (M0 körgyürü - északi szektor (P1)) azonosítható, amely mindkét értékelési mód esetén átlag alatti eredményt ért el. Ezek a számok szintén a sorrend átrendeződésére engednek következtetni.

A projektek rangsorának átrendeződését a két értékelési mód között, vagyis a válaszadók preferenciájának a költségadatok következtében történő változását jól példázza a Budapest Liszt Ferenc nemzetközi repülötér kötöttpályás kapcsolatának kialakítása (P3) című projekt, amely rendkívül népszerünek bizonyult, amikor arra a kérdésre kellett választ adni, hogy mely projektek megvalósítását támogatja a válaszadó. Ennél a kérdésnél a 2. legnépszerübb volt a reptéri projekt. Ezzel szemben, a költségvetési keret szétosztásakor, a projekt 191 milliárd forintos költségének ismeretében, már jóval kevesebb válaszadó tette be képzeletbeli projektcsomagjába a reptér közlekedési kapcsolatának fejlesztését, a tíz projekt közül csak a 8. leggyakoribb elemnek bizonyult a projektcsomagok képzésekor. Hasonló folyamat állapítható meg például a 650 milliárd forint becsült értékű Budapest elővárosi vasúti rendszerének fejlesztése (P10) címü projektjavaslat esetében, amely a 3 . helyről az utolsó, 10. helyre került a beruházási költség figyelembevételével meghozott döntéseknél. Ellenkező irányú átrendeződés figyelhető meg ezzel szemben a relatíve alacsonyabb, csupán 4 milliárd Ft becsült költséggel rendelkező Trolibusz jármübeszerzés és kapcsolódó infrastruktúra-fejlesztés (P5) címü projektjavaslat társadalmi értékelésében: a 10. helyről a 3. helyre lépett elö a sorban a költségvetési terv készítésekor.

A kérdésfeltevés formája tehát alapvetően befolyásolta a válaszadást. Teljesen más sorrend rajzolódott ki a projektek között a kétféle véleménynyilvánítási mód esetén. A válaszadók preferenciájának átrendeződése figyelhető meg akkor, ha nem csak a választási lehetőségek alapvető tulajdonságait, jellemzőit ismerik, hanem azok költségét kénytelenek figyelembe is venni. Ugyan az egyszerü támogatás (voting) funkció esetében is rendelkezésre álltak a költségadatok a projekteket leíró információk között, ennek támogatási szándékot befolyásoló hatása jóval kisebb mértékben jelentkezett, mint a kemény költségvetési korlátot alkalmazó költségvetés készítési (budgeting) funkció esetén. Az alacsonyabb költségü projektek számos esetben előrébb sorolódtak, amikor korlátos költségvetés szétosztása volt a válaszadók feladata. A nagyobb költségü projektek pedig rendszerint hátrébb sorolódtak a költségek figyelembevételekor ahhoz képest, mintha csupán arról kellett nyilatkozni, hogy általánosságban támogatja-e vagy nem a válaszadó az adott projektet. Ez a jelenség a pénzben kifejezett költségek érzékeltetésének fontosságára, döntést befolyásoló szerepére hívja fel a figyelmet. A két értékelési mód eredményei közötti különbözőség tehát nem módszertani hibára utal, hanem a társadalmi értékítéletben megnyilvánuló különbségekre. A költségvetés készítési funkció (budgeting) tehát felelősségteljesebb választásra, tudatosabb döntéshozatalra készteti a megkérdezetteket, míg az egyszerü támogatás (voting) a projektek általános népszerüségéről ad információt.

\section{KÖVETKEZTETÉSEK, TANULSÁGOK, TOVÁBBI KUTATÁSI IRÁNYOK}

A tesztben szerepeltetett projektek volumenüket és tartalmukat tekintve is vegyesek voltak. Szerepeltek kisebb és nagyobb költségigényü, valamint hálózati fejlesztést, bővítést, illetve csupán rekonstrukciót vagy amortizációpótlást tartalmazó projektek is. A tanulmányban bemutatott társadalmi egyeztetési folyamat során a létrehozott keretrendszer a Consul szoftver két funkcióját - voting és budgeting adaptálta. A két kérdésfeltevési mód egyaránt hasznos, különböző tartalmú információkat nyújtott, amelyek együttes alkalmazása kontroll funkcióval is szolgál a kapott eredmények értékelésekor, értelmezésekor. A budgeting teszt eredményeként átlagosan a költségkeret háromnegyede került elköltésre, amelynek alapján a válaszadók pénzügyi tudatossága feltételezhetö, míg a voting funkció a projektek általános népszerüségét mérte fel. A projektek rangsorában megfigyelhetö eltérés a kétféle értékelési eljárás esetén a költségvetési korlát jelenlétének kulcsfontosságú szerepére mutatott rá az egyéni preferenciákban. 
A vizsgálat továbbfejlesztése történhet az adatfelvétel körének szélesítésével, illetve új értékelési módszerek alkalmazásával is. Például egy megismételt, hosszabb teszt keretében a mintaelemszám növelése és a válaszadók attribútumainak elemzés céljából történő, szélesebb körü felvétele hozzájárulhat a társadalmi preferenciák részletesebb vizsgálatához. Az adatelemzéssel feltárható összefüggések körét bővítheti a válaszadók szociológiai attribútumainak felvétele, például az életkor, nem és lakhely ismerete. A projektek sokszínűsége és az alkalmazott kérdésfeltevési módok nagyobb mintaelemszám esetén számos további érdekes kérdés vizsgálatára nyújthatnak lehetőséget. Vajon társadalmilag elfogadhatóbbak-e a kisebb költségigényü projektek? Kedvezőbb-e a hálózati fejlesztést tartalmazó, új közlekedési kapcsolatot, eljutási lehetőséget létrehozó projektek társadalmi elfogadása, mint a csak rekonstrukciót, amortizációpótlást vagy hálózati fejlesztést nélkülöző egyéb projekteké? Milyen összefüggés tárható fel a projektek társadalmi értékítélete és tudományos alapokon nyugvó értékelése között? A voting és budgeting funkciók alkalmazásának eredményeként megfogalmazott következtetések árnyalására adhat lehetőséget a vizsgált projektek társadalmi értékelésének összehasonlítása a projektek tudományos alapon nyugvó értékelésével. Utóbbi kvantitatív értékelés esetén történhet például társadalmi (közgazdasági) költség-haszon elemzéssel (CBA) vagy kvalitatív értékelés esetén független szakértői értékeléssel készített multikritériumos elemzéssel (MCA). Mindkét esetben az értékelési módszerek eredményeként előállt mutatószámok alapján készített rangsorok összehasonlítása javasolható.

\section{A Consul platform egyszerü támogatás (voting)} és költségvetési terv készítés (budgeting) funkcióinak kombinált alkalmazásával különböző projektek, projektcsomagok társadalmi értékelése lehetséges, ugyanakkor a keretrendszer lehetőséget nyújt további három funkció debates, proposals, collaborative legislation adaptálására is, amelyek megvalósítására a bemutatott teszt során nem került sor. A debates funkció a társadalmi egyeztetést készítő szervezet által megadott projektjavaslatok szöveges véleményezésére ad lehetőséget. A proposals funkció alkalmazása az érintettek proaktív részvételét feltételezi a társadalmi egyeztetési folyamatban, önálló projektjavaslatok megfogalmazását teszi lehetővé. Tehát nem a megadott információtartalom értékelése, hanem a társadalmi szereplők igényeinek, ötleteinek összegyüjtése történhet e funkció használatával. A collaborative legislation funkció alkalmazásának tárgya különböző szöveges dokumentumok közösségi véleményezése. Ez a funkció a társadalom életét érintő számos dokumentum - például stratégiai tervek vagy jogszabály tervezetek - több felhasználó általi, szimultán észrevételezésére nyújt lehetőséget. Természetesen ezen három említett funkció a hazai közlekedésfejlesztési gyakorlatban nem teljesen új, ugyanakkor a Consul újszerü, formalizált módon történő alkalmazásukat teszi lehetővé, amelynek számos hozadéka lehet.

\section{A Consul eszköz öt funkciója (voting,} budgeting, debates, proposals, collaborative legislation) nemcsak társadalmi, hanem intézményi konzultáció lefolytatására is alkalmas. Projektek, projektcsomagok vagy szöveges dokumentumok esetében is jól meghatározott, transzparens keretek között történhet az intézményi szereplők közötti egyeztetés és véleménycsere. A platform lehetőséget biztosít projektek, stratégiai dokumentumok vagy egyéb adattartalmak megosztására, valamint térképi megjelenítési lehetőségeivel segíteni tudja egyes tartalmak térbeli vizualizálását. A Consul alkalmazáshatósága ezért nem csak a társadalmi egyeztetésekre korlátozódik, hanem szakmai, intézményi egyeztetések lefolytatására is javasolt. Az eszköz továbbfejlesztése nagymértékben hozzájárulhat más projektlisták sikeres társadalmi egyeztetéséhez, jövőbeli stratégiai, fejlesztési tervek, programok előkészítéséhez is.

\section{FELHASZNÁLT IRODALOM}

[1] NHS England, 2016. Developing a method to assist investment decisions in specialised commissioning: next steps, Consultation guide. April 2016, London. p. 22.

[2] National Infrastructure Commission, 2016. The national infrastructure assessment process and methodology, Consultation response. October 2016, London. p. 38. 


\section{Közlekedésfejlesztés}

[3] Crane, J., 2018. Why the history of public consultation matters for contemporary health policy. Endeavour, 42/1, pp. 9-16. DOI: http://doi.org/gdhdgh

[4] European Commission, 2013. A concept for sustainable urban mobility plans. COM (2013) 913 final, Annex 1. 17.12.2013, Brussels. p. 5.

[5] Wefering, F. et. al., 2014. Guidelines. Developing and Implementing a Sustainable Urban Mobility Plan. January 2014. p. 151.

[6] Esztergár-Kiss, D. - Tettamanti, T., 2019. Stakeholder engagement in mobility planning. Autonomous. Vehicles and Future Mobility 2019, pp. 113-123. DOI: http://doi.org/ddpk
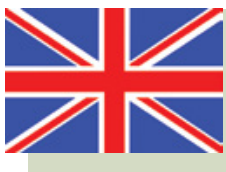

Social Consultation in the Service of Transport Development - The lessons drawn from the Adaptation of the Consul Framework System

Public participation gains more and more importance in the process of implementing public developments. This paper describes the method and results of the public consultation process of 10 transport development projects relating to Budapest and its agglomeration. The research has been carried out under the framework of the SMART-MR Research \& Development project which can significantly contribute to the success of future social evaluation processes. The public consultation was conducted by implementing the Consul public software tool using its modules, voting and budgeting. Results have shown the financial consciousness of respondents in the presence of a budget constraint.
[7] TRENECON, 2017. Módszertani útmutató a Fenntartható Városi Mobilitási Terv (SUMP) készítéséhez. Nemzeti Fejlesztési Minisztérium, Budapest. p. 51.

[8] https://consulproject.org/

[9] Trans-Sport Consulting, 2019. Az IKOP javítását célzó SMART-MR akcióterv öszszeállítása, Helyzetfeltárás, értékelés és javaslatok. BKK Zrt., Budapest. p. 95.

[10] https://bkk.hu/2019/01/smart-mr-consuleszkozt-tesztel-bkk/

[11] 1247/2016. (V. 18.) Korm. határozat az Integrált Közlekedésfejlesztési Operatív Program éves fejlesztési keretének megállapításáról

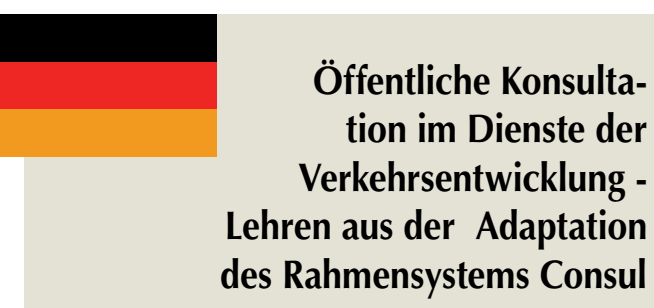

Die Bürgerbeteiligung der Öffentlichkeit gewinnt bei der Umsetzung öffentlicher Entwicklungen immer mehr an Bedeutung. Diese Studie beschreibt die Methode und die Ergebnisse des öffentlichen Konsultationsprozesses von 10 Verkehrsentwicklungsprojekten im $\mathrm{Zu}$ sammenhang mit Budapest und seiner Agglomeration. Die Analyse wurde im Rahmen des SMART-MR Forschungsund Entwicklungsprojekts durchgeführt, das maßgeblich zum Erfolg künftiger sozialer Evaluierungsprozesse beitragen kann. Die öffentliche Konsultation wurde durchgeführt, indem das öffentliche Softwaretool von Consul unter Verwendung seiner Module, Abstimmung und Budgetierung implementiert wurde. Die Ergebnisse haben das Finanzbewusstsein der Befragten bei vorhandenen Budgetbeschränkungen gezeigt. 